\title{
The Politics of Immigration Locally: Alliances between Political Parties and Immigrant Organizations.
}

\author{
Juan Carlos Triviño-Salazar \\ Institut Barcelona d'Estudis Internacionals (IBEI), Barcelona, Spain
}

ORCID: 0000-0002-1159-9835

Article history: Received 4 April 2016; Accepted 17 January 2017

\begin{abstract}
Alliances are a political opportunity that reinforce the claims made by different players in the political sphere. However, the literature on the political participation of immigrants pays little attention to the formation of alliances and their effects on the interaction between immigrants and institutional actors, especially under circumstances of politicization. This article aims to explain the emergence of alliances between political parties and immigrant organizations when immigration is politicized locally. I argue that the need to legitimize the political parties' position on the politicization guide their alliances with immigrants. Using qualitative methods, I analyze the emergence of alliances in the anti-Romanian-Roma campaign in Badalona and the burka ban in Lleida, both in Catalonia, Spain. The findings portray these relationships as the outcome of strategic interactions that respond to the balance of power between institutional and non-institutional actors.
\end{abstract}

\section{Keywords}

Alliances, immigrant organizations, local, political participation, politicization, political parties 


\section{Introduction}

From demonstrations on the streets to winning elections, allies reinforce the objectives and aspirations of specific political actors in the political sphere (Kriesi 2004, 69). Hardly any mention in the literature of the political participation of immigrants is made to alliance formation and its effects on immigrants and specific institutional players. This is especially relevant if we think of immigration as one of the most politicized issues in Western Europe and North America. Instead, the focus is on the way institutions in host societies shape the mobilization and organization of immigrants at different levels of government (Koopmans and Statham 2000; Ireland 2004; Garbaye 2005; Hoschild and Mollenkopf, 2009; Giugni and Morales 2011).

Against this background, this article seeks to answer the following question: why do alliances between political parties and immigrant organizations emerge when immigration is politicized at the local level? I argue that alliances are guided by the political parties' need to legitimize ${ }^{2}$ their position vis-à-vis the politicization of immigration. Based on Kriesi (2004) and Diani (2015), I define alliances as the relationship between two actors, potentially unequal in terms of power, that emerge from the support lent by one side or the other with the aim of exchanging resources and achieving short-term or long-term goals. In this definition power is a relational concept where an actor has the ability to change the incentive structure of another to obtain the outcomes they desire (Dowding 1991, 68). Alliances are vital to political parties because they reinforce their strategic and ideological position with their electorate (Kriesi 2015, 675). For immigrant organizations, political parties as an elite ally have the potential to put forward their claims in policy-making (Ireland 2004, 25).

I locate alliances in contexts of politicization of immigration. Politicization refers to immigration being placed front and centre on the political agenda (van der Brug, et al. $2015,3)$. It is a process that follows top-down or bottom-up dynamics depending on the type of actor, their interests and the momentum. My argument is largely top-down where political parties along with governments are responsible for determining the politicization or de-politicization of immigration (Ruedin and Meyer 2014; van der Brug et al. 2015). The local level is highly relevant in politicization because it is the proximity context where institutional actors act and react, oftentimes before they do at

\footnotetext{
${ }^{1}$ Juan Carlos Triviño-Salazar, e-mail: jctrivino@ibei.org
}

\section{${ }^{2}$ Notes}

Suchman defines legitimacy as the "generalized perception or assumption that the actions of an entity are desirable, proper, or appropriate within a social system" $(1995,574)$. 
the national level, to the claims of immigrants and local population (Giugni and Morales 2011,9).

To answer my question, first, I tackle the gap regarding alliances by proposing an analytical framework that draws its logic from the literature on social movements using the political opportunity (POS) approach. Then I study two cases of politicization in the cities of Badalona and Lleida in Catalonia, Spain in 2010-2012 using qualitative methods. Afterwards I discuss the role of political parties in shaping the opportunities of participation for immigrant organizations via alliances.

\section{Alliances in the immigration literature}

The concept of alliances draws its logic from social movement scholars following the political opportunity (POS) approach (Tarrow 1994; Rucht 2004). These scholars argue that the configuration of actors structures the relationships among social agents and their elite allies (e.g. the legislature, the judicial system, political parties). The alignment of common objectives between two actors and the ties developed define the emergence of alliances (Kriesi 2004, 305). In spite of their remarkable importance, few studies in the literature explicitly focus on alliances. They tend to examine the institutional and cultural factors that explain immigrants' mobilization strategies nationally and locally (some exceptions are Garbaye 2005 and Cappiali 2016).

The literature focusing on the national level suggests that the mechanisms used by host states in their affairs with immigrants produce political opportunities that shape their identities and their mobilization patterns (Martiniello, 1993; Jones-Correa 2005; Koopmans, et al. 2005; Alba and Foner 2015). Empirical studies focus on those national features in the political system that define the collective actions of immigrants at different levels of government (Bousseta, 2000; Ireland 2004). Political opportunities are related to citizenship regimes, which determine formal access to residence, and integration models, which determine the cultural obligations that this access entails (Koopmans and Statham 2000, 24).

Conversely, the literature focusing on the local level defends the city as the first arena where the policy challenges of integrating immigrants are experienced. It also defends it as the level that shapes the political opportunities for their collective participation (Borkert and Caponio 2010; Giugni and Morales 2011). The literature has paid special attention to the presence of immigrants in local policy or social networks (Caponio 2005; de Graauw and Vermeulen, 2016), their representation in political institutions (Garbaye 2005) and the formation of immigrant organizations (Fennema and Tillie 2001; Vermeulen 2006; Ramakrishnan and Bloemraad 2008). Some authors also advocate for the complementarity of the national and local approaches (Hochschild and Mollenkopf 2009; Però and Solomos 2010).

The study of actors is part of a growing debate on the relevance of institutional and cultural factors that shape how immigrants participate politically. Against this backdrop, 
the relevance of alliances for specific actors and the existing gap in the literature beg for analytical tools to study them.

\section{An analytical framework to study alliances}

Potential allies will probably look for those actors they perceive as their closest and most reliable (Diani 2015, 145-150). Identifying an issue and a common adversary may bring two actors together (e.g. a law deemed unfair, an electoral campaign, a terrorist attack) (Diani and Bison 2004, 285-286). Nevertheless, merely expressing support for a position on a particular issue is not sufficient for an alliance to emerge. It is a first step followed by the agreement on common goals (short or long-term), the interaction between agents and the exchange of resources (Smith and Fetner 2010). Diani states that, "organizations secure resources through alliances, but also operate a reduction of systemic uncertainty" $(2015,51)$.

Researchers studying these relationships acknowledge that not all actors have the same resources; this situation reflects the unequal power relationship between allies (Meyer and Staggenborg 1996; Diani and Bison 2004). The balance of power is especially important when speaking of political parties with access to decision-making bodies and immigrant organizations attempting to obtain external resources through allies (Allern and Bale 2012). Based on these premises, I introduce three interconnected dimensions in the formation of alliances from the intersection of the literature regarding social movements (Morris and Staggenborg 2004, Diani 2015, Kriesi 2015) and the political participation of immigrants (Martiniello 1993; Vermeulen 2006): positions, leaderships and incentives.

\section{1) Positions}

The position an actor assumes on specific issues can signal the relationship they will have with others (Giugni and Passy 1998, 17). A set of actors with similar objectives has the capacity to strengthen their individual positions when they join forces (Rucht 2004, 202). The politicization of immigration produces salience-relevance on the political agenda - and polarization-division - among the parties involved (van der Brug, et al. 2015, 10). Therefore, we can expect agreements and disagreements among the actors which generate, in turn, cooperation or conflict (Koopmans et al. 2005, 146). As an example, the Socialist Party (PS) in France garnered sympathies from the urban-based 'Sans Papier' movement for the regularization of undocumented immigrants when it publicly supported their demands (Iskander, 2007). The situation helped to establish ties that later on evolved into alliances in favour of the PS' electoral campaign for the National Assembly. Accordingly, this dimension seeks to identify and understand the positions assumed by political parties and immigrant organizations on the politicization of specific issues. 


\section{2) Leaderships}

Social movement leaders seek to legitimize themselves as the valid contact point for their own communities with the purpose of mobilizing resources otherwise difficult to obtain (Morris and Staggenborg 2004, 171). They are entrepreneurs who mobilize in response to incentives, risks and opportunities (McCarty and Zald 1973). Institutions and institutional players have a role in shaping how leaders act and react (Ireland 2004; Garbaye 2005). Knoke and Wright-Isak distinguish the leaderships within social movements according to the motivations they have to mobilize as cost-benefit oriented or value-oriented (1982). The adaptation of Knoke and Wright-Isak's typology to this study is useful to better understand the motivations immigrant and ethnic leaders have when negotiating the formation of alliances with political parties.

Cost-benefit oriented: Leaders mobilize motivated by the procurement of private goods whose benefits are limited to themselves and their group. Their motivation is based on a calculation based on individual considerations.

Value-oriented: Leaders mobilize motivated by the prospect of achieving a common good beyond themselves or their group. Their motivation is based on standards of conduct governed by values and principles.

The importance of this distinction is illustrated by the protests against the 2001 Spanish Foreigners Law when groups of undocumented immigrants occupied churches in Barcelona (Però 2007, 278). The immigrant leadership was organized along two lines: (1) those who supported the protest because of their cosmopolitan ideals that justified their actions and (2) those asking the groups to stop the protests because of their fear of endangering their access to Catalonian and local political institutions.

\section{3) Incentives}

Political authorities create 'systems of incentives' or 'rewards' for social actors when negotiating alliances (Edwards and McCarthy 2004, 116). As a rational actor, political parties create systems of incentives to negotiate the support other actors can give to their programmes (Dowding, 1991). However, it is also true that the type of incentive may change according to the circumstances surrounding those offering them. The Socialist party in France changed the incentives social movements (environmentalist, peace, immigrant movements) were offered before and after François Mitterrand became president in 1981. In the seventies their incentives sought to appeal to protest movements seeking to change the status quo; in the eighties, when they were in power, their incentives favoured more institutionalized and less vocal groups that maintained the status quo (Kriesi, et al. 1995, 62). Based on Clark and Wilson (1961) and Knoke 
(1988), this dimension looks at three types of incentives political parties may offer immigrant organizations in the process of negotiating an alliance.

Quantifiable: tangible rewards translatable into monetary assets (e.g. job prospects, grants, money).

Solidary: intangible rewards from associating. They do not have monetary value as they relate to the recognition that one organization can make of individuals and organizations relevant to their interests (e.g. certain prestige among their peers).

Purposive: intangible rewards linked to value fulfilment. The opportunity for major change in the status quo is the incentive for those engaging in collective action (e.g. protests to oust an authoritarian government).

\section{Selecting two cases of politicization at the local level in Spain}

Local governments and political parties are important protagonists when it comes to deciding to include integration on the political agenda of Spanish cities (Arango et al. 2011 , 9). Due to how competencies are allocated in the country, the integration of immigrants via policies is mainly a local responsibility. This is especially important given that from 2000 to 2008 Spain had the most rapid growth in the number of immigrants in Europe and the second most in the OECD countries (Arango et al. 2011, 3). The immigrant population increased from 1 million in 2000 to 5.5 million today, or 12 per cent of the total population of 46 million (INE 2015). Among the 17 Spanish Autonomous Communities, Catalonia had the most spectacular rise in its immigrant population (from $2 \%$ in 2000 to $16 \%$ in 2012) (INE 2015).

In Catalonia, the sharp demographic increase combined with the 2008 financial crisis turned political heads towards immigration (Burchianti and Zapata-Barrero 2014). In the lead-up to the May 2011 local elections, specific immigration issues became highly politicized. During this time, mainstream political parties - the centre-right People's Party (PP), the centre-left Socialist Party of Catalonia (PSC) and the Catalonian centre-right Convergence and Union (CiU) - hardened their discourse on immigration by targeting immigrant communities in certain cities. The cities of Badalona (pop. 132,000/15 per cent immigrant) and Lleida (pop. 137,387/21 per cent immigrant) became representative of this move because for the first time mainstream political parties dared to include reactive discourses and policies on the local agendas of mid-sized cities. The remaining relevant political parties in this period were the Catalonian left-wing Republican Left of Catalonia (ERC), the Catalonian left-wing Initiative for Catalonia-Greens (ICV), the Catalonian left-wing Popular Unity Candidacy (CUP) and the centre-right Citizens (Cs). 
Following qualitative methodology, I studied the cases of the anti-Romanian-Roma campaign in Badalona and the burka ban in Lleida, both in Catalonia, in 2010-2012. The selection follows the diverse case method to achieve maximum variance along relevant dimensions (on/off, red/black/blue, Jewish/Protestant/Catholic) (Seawright and Gerring 2008, 300). I used categorical variables of interest related to the independent variable of my research question: the politicization of immigration at the local level. Following Koopmans et al. (2005, 148) and Kriesi (2015), my selection criteria was based on first, the politicization of two different types of cultural issues (ethnic or religious) and second, a process of politicization led by different mainstream political parties in the political spectrum (left-wing or right-wing). The application of the criteria resulted in the cases of Badalona as an ethnic issue politicized by a centre-right political party (PP) and Lleida as a religious issue politicized by a centre-left party (PSC) (see Table 1).

Table 1. Selection criteria

\begin{tabular}{|l|l|l|l|}
\hline Cases & $\begin{array}{r}\text { Dependent variable } \\
(y)\end{array}$ & \multicolumn{2}{|c|}{ Independent variable (x) } \\
\cline { 2 - 5 } & Presence of alliances & x1. Type of issue & x2. Political spectrum \\
& politicized & \\
\hline Badalona & Yes & Ethnic issue & Centre-Right (PP) \\
& & Religious issue & Centre-Left (PSC) \\
\hline Lleida & & & \\
\hline
\end{tabular}




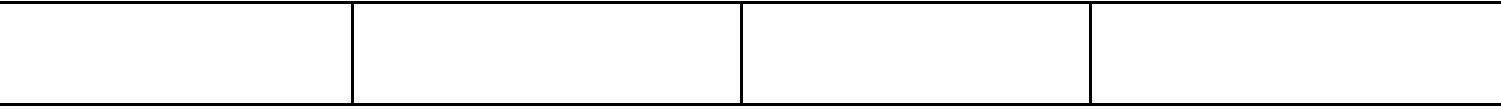

\section{The anti-Romanian-Roma campaign in Badalona}

The city of Badalona, the third largest in Catalonia and a Socialist stronghold, was ruled in 2007-2011 by a coalition of three parties: the center-left PSC, the Catalonian centre-right CiU and the Catalonian left ERC. In May 2010, Xavier Garcia-Albiol, then a PP candidate for mayor, distributed a leaflet negatively referring to immigrants and Romanian-Roma in the city. Since the 2007 local elections, the PP in Badalona repeatedly tried to politicize the presence of immigrants and specific ethnic communities (Triviño-Salazar 2014). The sharp increase in their number and their arrival to neighbourhoods on the outskirts of the city produced tension in the public space while generating the perception that there were some communities less integrated than others. Amidst heated controversy due to his campaign, Garcia-Albiol was elected and promised to control and expel "problematic" immigrants, especially Romanian-Roma ones. Because of the PP's campaign, the NGO SOS-Racisme sued him for hate speech although Barcelona's Criminal Court found him not guilty in 2013.

\section{The burka ban in Lleida}

On June 29, 2010, Lleida's local council approved the modification to the local law of civility which forbade access to public buildings of any person wearing burka or niqab or other accessories such as helmets or balaclavas. The centre-left PSC, as the governing political party, proposed the modification. Although the government recognised that few women wore burkas in the city, the measure was officially sanctified on security grounds and the defence of gender equality (Triviño-Salazar, 2014). The ban made Lleida the first Spanish city to pass this kind of regulation. Political and social players at the local and national levels considered the ban an intrusion into religious affairs that stigmatised Muslim immigrant communities. In fact, the second and third most important immigrant communities in the city were nationals from Morocco and Algeria. The Spanish Supreme Court late ruled that the city had exceeded their attributions and declared the ordinance unconstitutional.

\section{Data and methods}

The analysis relies on desk research and semi-structured interviews. Desk research was useful to identify the most relevant actors and trace the evolution of the cases within their contexts. In total, I selected 125 newspaper articles from the six most widely read newspapers in Catalonia by using keywords in databases such as Factiva or Mugak (Spain) and six local councils' proceedings. Semi-structured interviews were the 
most important technique because they gave me access to the narratives of the different players involved in the specific cases. I conducted twenty-seven interviews in Spanish from March to June 2013. In Badalona, I interviewed four council members, three leaders of local Roma organizations, ${ }^{3}$ three leaders of local pro-Roma organizations and I had informal conversations with local Roma and immigrant leaders. In Lleida, I conducted interviews with five council members, a political party's local president, five Maghrebi organizations, five pro-immigrant organizations and a city government civil servant. Political parties' representatives in the local councils were interviewed because of their access to the decision-making structures. A snowball sample technique guided the selection of immigrant organizations.

I used thematic analysis in order to process all the information gathered for the research. Thematic analysis is defined as "a method for identifying, analyzing and reporting patterns (themes) within data" (Braun and Clarke 2006 79). A theme can be a short sentence highly relevant for answering the research question or the patterned repetition of certain information (Boyatzis 1998). In my research, the themes were theory-driven and based on the analytical framework. Although this form can provide a less rich description of the information gathered, it gives a more detailed analysis of some parts of the information. For instance, in the dimension on leadership, I read the interviews several times to identify those themes related to cost-benefit oriented motivations. I identified this through keywords and the context of the conversation:

"It is true that the Roma leaders are very used to having a relationship with the government where they see 'what they can get'."

Pro-Roma NGO representative, interview, April 12, 2013

\begin{abstract}
${ }^{3}$ I selected local Roma organizations because (1) most of them defended the Romanian-Roma community as co-ethnics; (2) Roma people, as Muslims, were constructed as outsiders in the two cases; and (3) these organizations had members from diverse backgrounds (local-Roma; Romanian-Roma; community leaders and immigrants). I based this choice on the theoretical distinction between beneficiaries and conscience constituents/adherents developed by McCarthy and Zald (1973). Those groups that directly benefit from the outcome of their mobilization are considered beneficiaries while those that do not are considered conscience constituents/adherents.
\end{abstract}

\title{
Acknowledgements
}

I am grateful to Avi Astor, Andrea Bianculli, Karen Bird, Flora Burchianti, Tiziana Caponio, Teresa Cappiali, Blanca Garcés-Mascareñas, Marco Martiniello, Ixchel Pérez-Durán, Ricard Zapata-Barrero and the anonymous reviewers for their valuable comments on previous versions of this manuscript. 
Due to the scope of this study, I did not focus on the internal dynamics of political parties and immigrant organizations and in other relationships that might have emerged with other actors. Although I consider them relevant to the overall understanding of alliances, my interest was to reveal the ties that explain the emergence of alliances between two highly relevant players for immigrants at the local level.

\section{The emergence of alliances in Badalona and Lleida}

Based on the fieldwork, it was possible to identify the formation of alliances in the two cases studied. Whereas the PP in Badalona formed alliances with some local Roma organizations defending the anti-Romanian-Roma campaign, ICV formed alliances with local Roma organizations opposing it. In Lleida, the PSC formed alliances with immigrant organizations representing Muslim immigrants from Morocco and Algeria (Maghreb Region) and CiU established an alliance with an immigrant organization. I applied the analytical framework described above to identify the main elements that contributed to the alliance formation.

\section{The Anti-Romanian-Roma campaign}

The positions (1) assumed by the different political parties involved in the anti-Romanian-Roma campaign were quite homogenous with the exception of the PP for obvious reasons. The salience of the issue in the city and the positioning of important sectors of the local Roma community in favour of the PP's discourse validated their message among the population. The main argument was to defend the city against the threat posed by 'uncivil foreign residents.' They portrayed the Romanian-Roma community as the culprit of all the evils brought by immigration: crime and abuses in the welfare state (El País, April 3, 2010). Xavier Garcia-Albiol, then candidate for mayor, proposed to use the police to arrest Romanian-Roma perpetrators and send "them [back] to wherever they came from" (interview in $L a$ Vanguardia, April 25, 2010).

The position of political parties and immigrant organizations opposing this particular issue was aligned. The then ruling coalition (centre-left PSC, Catalonian centre-right $\mathrm{CiU}$, and Catalonian left ERC) and opposition ICV (left-wing, green) were against the campaign. The PSC criticized the PP's arguments calling them inflammatory and in conflict with Badalona's social cohesion (proceedings, Plenary Session, September 28, 2010). The ICV portrayed Garcia-Albiol as a "demagogue" who ignored the socio-economic conditions of immigrants and marginalized groups (ICV councilman, interview, March 21, 2013).

In the Roma community, the lack of clear leadership and organization among the Romanian-Roma residents prevented them from playing a more relevant political role (pro-Roma NGO, interview, May 23, 2013). Therefore, the main political target during the Romanian-Roma controversy was the local Roma community. The informal leaders 
within the community - the local Roma patriarchs - positioned in favour of the PP and organizations linked to the patriarchs publicly showed their support. Conversely, local Roma organizations, with members from diverse backgrounds (immigrant and local) mainly concentrated in the Sant Roc neighbourhood took over the defence of Romanian-Roma residents. For them, the nationality of the Romanian-Roma people was irrelevant, as they saw them primarily as co-ethnics.

We are co-founders of this country [meaning Europe] but the degrading way they treat us of us is historical. Because with the gypsies they don't care what they do, there is no other group in Europe as mistreated as ours. There is an educational model that is not giving the Roma people answers, and Europe knows that.

Roma leader, interview, May 4, 2013

The local Roma leaderships (2) in Badalona can be divided into two types: the traditional patriarchs who are the informal leaders of the community that mediate in conflict and negotiate with other groups (e.g. political parties) and the leaders that represent the local Roma residents and immigrants in certain areas of the city. The local Roma patriarchs supporting the PP followed cost-benefit oriented motivations when forming alliances with this party. Traditionally, the patriarchs have functioned as "families" looking for gains for their members mainly by distributing material benefits. In some cases these "families" had formalized organizations in the city, but the leaders were still the patriarchs. They negotiated the alliances with the party in a way that replicated the traditional interaction they had had with the local political elites in the past. The PP, on their part, contacted them when the Romanian-Roma controversy started.

You have the Roma community, and you say: ok, let's divide them. You look for a couple of influential patriarchs that can help us expel these people [...]. After that you have a situation where the Spanish Roma community is against the Eastern European Roma community, their own people [...]. It is orchestrated by governments and leaders who set them against themselves.

Pro-Roma NGO, interview, May 6, 2013

For those leaders who were opposed to the PP, they followed more value-oriented motivations in forming alliances with ICV. They grouped themselves into a coalition formed by Roma and immigrant organizations that defended the Romanian-Roma residents and the immigrant population in general. This coalition received the strong support of one council member from ICV who had worked with them in the Sant Roc neighbourhood. In spite of the efforts of their leaders to mobilize their communities against the reactionary line held by the PP, their scarce recognition by the community rendered their message ineffective (pro-Roma NGO, interview, May 3, 2013). Their 
motive was to defend an intercultural model of coexistence for all the communities in the city (Roma leader, interview, May 4, 2013).

The last stage in the process of alliance formation was completed by the offer of quantifiable incentives (3) from the PP and purposive ones from ICV to local Roma leaders and organizations. The situation made evident the division within the Roma leaderships on the issue and how local Roma organizations and informal leaders interacted with these parties along the lines of that division.

The PP offered quantifiable incentives during the electoral campaign and when they won the elections in May 2011. According to the interviewees, during the campaign representatives from this party gave money to those leaders (some patriarchs and aides) that supported them; they also promised to provide them with government grants if they won the elections. When the PP won the elections, they delivered on their material promises. Through the government, they funded the creation of several organizations led by leaders who supported them (pro-Roma NGO representative, interview, April 12, 2013). However, the financial constraints on public coffers made them short-lived. Conversely, ICV offered purposive incentives related to the defence of a proactive approach to the coexistence of city residents. They based their offer on providing the know-how to organize their opposition to the PP and to expand their network of social actors in favour of an intercultural direction (Sant Roc Platform leaders, interview, April 22, 2013). To them, it was important to maintain their electorate content from an ideological point of view by firmly holding their position. The incentives offered to Roma organizations matched this view.

Unlike ICV and its allies, the governing coalition did not offer any incentives. This might be due to the interest the coalition parties had in channelling the issue through the government. Additionally, the passive role of the governing PSC and specific local Roma leaders, possibly due to the salience of the issue, deterred any contact from being made.

\section{The burka ban in Lleida}

The burka ban in Lleida produced different positions (1) between the two sets of actors. The ruling party (PSC) proposed the ban while the PP and CiU supported it. ERC abstained and ICV voted against it (City of Lleida, Plenary session, July 2, 2010). The PSC, PP and CiU based their support on the defence of the local system of values in response to more conservative Muslim communities. In more practical terms, the burka ban was considered a symbolic measure to express the type of Islam acceptable in the city. CiU and the PP also based their support on their position on immigration as centre-right political parties advocating for organized immigration flows and cultural affinity with the host society, in this case Lleida. ICV, the only party that voted against the ban, justified their position stating that the burka was a created problem, not a real 
one (ICV local president, interview, June 3, 2013). They promoted a different approach based on education and dialog.

Immigrant organizations representing residents from Muslim countries assumed two different positions: one that supported the ban out of the need to reject practices that they did not consider part of Islam and another that claimed that the ban was discriminatory and based on anti-religious sentiment. Some organizations supporting the measure aligned with the PSC's position to stop more conservative sectors of the Muslim communities that were against the image of a modern, European Islam (Moroccan organization representative, interview, June 5, 2013). Other organizations opposed the burka ban because they considered it a direct attack on their religious beliefs. However, there was a consensus that the politicization of the burka was an electoral strategy carried out by the PSC, CiU and PP. The interviewees felt it was an invention to deviate public opinion's attention from more pressing issues. For them, the PSC's need to retain power in an economic crisis was the reason for their choice to put this issue on the agenda.

They were only looking after their partisan interests [...] from that time [the burka debate], the problem with the Salafists that sparked the mosque debate emerged [Imam Houzi's community]. I mean, there are so many things, if you wear a beard and a tunic $[\ldots]$ they hate us. Just because of the tunic and the beard.

Muslim leader, interview, June 3, 2013

In terms of leaderships (2), the religious component (Islam) provoked the involvement of religious, national-oriented (Maghrebi) and cross-sectional organizations (e.g. Muslim women). However, those leaders representing Maghrebi organizations were the main participants involved in negotiating alliances with the PSC. The more secular approach followed by the political parties favoured the visibility of Magrebian leaders representing national-oriented organizations. In fact, these leaders negotiated their alliances with those political parties supporting the burka ban. The process of negotiation followed cost-benefit motivations based on the leaders' personal relationships with the political parties. Leaders mobilized due to the potential gains derived from their recognition as valid intermediaries for their communities.

All the political parties try to establish a relationship with the community. From this situation, you can get one thing or the other. For example, if you have a relationship with a party or you are a member [of that party] and you talk with the leaders, then you can obtain certain things.

Maghrebi leader, interview, June 5, 2013

The more 'religious' leaders either did not seek allies or were left out of the negotiation of alliances due to the lack of interest from the political parties in working 
with them. Moreover, their presence was mainly limited to giving public statements to the media. This situation reflected the interest of those political parties politicizing to acknowledge only those secular leaderships close to their position on the controversies.

Those political parties that formed alliances (governing PSC and opposition CiU) offered solidary incentives (3) to Maghrebi organizations. The PSC invited Maghrebi organizations close to the party's local section to informational sessions where they explained the reasons behind their decision. For the PSC, as a centre-left party, allegedly immigrant-friendly, it was important to demonstrate that Muslim immigrants from the Maghreb region legitimized their position.

I spoke $[\ldots]$ with people from the political party about this issue, people who come from other countries and belong to these communities and organizations. The truth is that everyone agreed on this. Some of them even told me: it was about time [for the ban]. Imagine that $[\ldots]$.

PSC council member, interview, June 6, 2013

For the organizations supporting the PSC, the invitation implied acknowledgment of their existence in a context of competition with other organizations. Being recognized by the governing political party turned the leaders into valid representatives of their communities.

'When you have a big problem [like this one], you need to look for people, political parties that can help you. You need to look for allies so you can be reinforced and impose what you want $[\ldots]$ '

Maghrebi leader, interview, June 5, 2013

CiU sought the support of the organization Nous Catalans (New Catalans) by contacting Maghrebi members who supported their position (Maghrebi leader, interview, June 3, 2013). It should be noted the endogenous situation in their relationship with CiU since the organization was founded and is funded by this party. The remaining political parties either did not find any allies to support their position (as in the case of ICV) or decided not to get involved in the search of support among Maghrebi organizations. In the latter situation, they deemed it difficult to ally themselves with anyone without "personal or material possibilities to reach agreements" (PP council member, interview, June 5, 2013).

\section{Alliances at the local level and the role of power}

Why do alliances between political parties and immigrant organizations emerge when immigration is politicized at the local level? The findings presented above portray them as a political opportunity for immigrant organizations; more importantly, alliances 
epitomize the political parties and politicians' power. For the latter, their access to the resources immigrant organizations need (e.g. funding, know-how, networks) combined with the context of electoral competition reinforced their position. For immigrant organizations, promoting their leaders' interests or their communities' aspirations informed the alliance formation (Vermeulen, 2006). These situations leave us three particular observations related to more pragmatic or idealistic rationales in alliance formation and a more general remark.

First, alliances between political parties that politicize or support the politicization of an issue and certain immigrant organizations emerge with a more pragmatic rationale. As in the case of the PP and some Roma organizations in Badalona, the alliance is predominantly driven by more practical and instrumental goals. For the parties, the politicization seeks to polarize salient issues for the electorate to increase their chances of continuing in government (office-seeking behaviour) or getting into government (vote-seeking behaviour) (Strom 1990). For them, the formation of alliances contributes to the creation of "networks of legitimization" that "rubber-stamp" their position in the eyes of their own party, voters and potential constituents. For immigrant organizations publicly expressing support for politicization, cost-benefit oriented leaders seem to be more open to negotiating the terms of cooperation with the political parties because they are motivated by the search of private goods that benefit themselves and their organizations. These leaders are more prone to accept quantifiable (as in the case of Badalona) and solidary incentives (as in the case of Lleida) because they match their more material motivations in the middle of the politicization.

Second, alliances between political parties that oppose the politicization and certain immigrant organizations emerge with a more idealistic rationale. As in the case of the ICV and some Roma organizations in Badalona, the alliance is driven by normative aspirations related to the understanding of a common good. This does not imply that these alliances do not have pragmatic elements just that they are a channel to reach higher goals. For the political party, the alliance legitimizes endorsing policy models that benefit the affected communities and local city residents. For the immigrant organizations, the alliance is based on the need to have a voice in the policy-making structures precisely to put forward more proactive integration policies. Value-oriented immigrant and ethnic leaders accept the terms of cooperation with political parties based on the need to reassert the model of coexistence they want for their communities. For political parties offering purposive incentives, their willingness to be ideologically consistent and disciplined with their political programme is an attempt to favour maintaining their electorate, albeit small, content. For immigrant organizations, the accomplishment of changes that favour the common good outweighs the prospect of other incentives (Knoke, 1988, 315).

Third, in cases of non-alliances, the participants weigh the benefits of getting involved in politicization and subsequent alliances. A plausible explanation for non-alliances is that political parties might want to depoliticize an issue that could harm 
them in elections (van der Brug, et al. 2015). They might also be unable to change the incentive structure leaving them with no allies among immigrant organizations. This explains why the PSC in Badalona and PP in Lleida did not form any alliance while the PP in Badalona and the PSC in Lleida did. For immigrant organizations, the reasons not to form alliances might be related to their unwillingness to assume a public position that is divisive internally, because they are concerned about losing access to specific institutional gatekeepers or due to their inability to find allies among political parties.

An overarching element in the findings is that alliances reflect what Dowding defines as the social power or "the ability of an actor to deliberately change the incentive structure of another actor or actors to bring about, or help bring about outcomes" (1991, 48). Alliances represent the alignment of supply and demand mechanisms where power plays an essential role in explaining their emergence. Following Axelrod, the politicization of specific issues creates conflicts of interest, or incompatibility of the actors' preferences, that permeate the context of electoral competition $(1970,50)$. This situation, in turn, changes the incentive structure for immigrant organizations. The three dimensions of the analytical framework in some ways mirror the aforementioned power while reasserting that having an ally is useful for reaching one's objectives (Edwards and McCarthy, 2004; 116). Sharing a common position on the politicization of an issue is a condition sine qua non to explore the possibilities of establishing alliances (Giugni and Passy 1998, 17). However, bridging elements that allow the negotiation of support and cooperation with ethnic and immigrant leaders are also necessary for this equation. Political parties select immigrant organizations based on the previous knowledge they had of certain leaders (as in the case of the governing PSC in Lleida) or by searching for receptive leaders during the height of conversation about the politicized issues (as in the cases of the PP and ICV in Badalona). On the immigrants' side and following Breton (1964), leaders accept, for themselves or their organizations, incentives aligned with their motivations. For the immigrant organizations they represent, preference for certain incentives over others is connected to the priorities they have as a collective. More importantly, the preference is strongly linked to the overall position of the political parties they ally themselves with in the politicization of an issue.

Political parties develop, "strategies of legitimization" that start with the engagement of immigrant organizations. As Schattschneider states, political parties ask themselves "which battle do we want most to win?" (1960, 67). The power they exert over immigrant organizations under the studied circumstances reflects their own incentives to compete against other political options (Dowding, 1991). Cox explains the importance of strategic coordination between parties and voters in order to maximize their chances of winning and reducing the number of competitors (1997, 5). Politicizing an issue polarizes while the competition with other parties is an incentive to position the party before the electorate. A party may deem the creation of alliances necessary or not or prefer certain allies over others to reinforce their position. As the alliance formation in this study shows, the power one actor has or how they employ it may define other 
actors' behavior in environments of competition and conflict (Kriesis et al. 1995; Kriesi 2015).

\section{Conclusion}

Introducing the study of alliances with political parties is tremendously important to understand how the opportunities immigrants, as a collective actor, have for political participation are structured. This paper highlighted the role of politics and politicians in shaping the behaviour of non-institutional actors in contexts of politicization at the local level. Political parties mediate between the claims of social actors, such as immigrant organizations, and political institutions (Kriesi 2015, 668). For immigrant organizations, their goal is to better position themselves vis-à-vis institutional gatekeepers with access to resources that justify their raison d'être: the claims and aspirations of immigrant communities. The contribution to the literature demonstrates that alliances between political parties and immigrant organizations follow strategic interactions that respond to the balance of power among themselves and the context of politicization. As mentioned above, power and its use informs more pragmatic or idealistic rationales in the alliance formation.

The alliances developed between the actors studied at the local level also contribute to understanding the city as a context of proximity that facilitates certain dynamics like the ones studied herein. Focusing on alliances between political parties and immigrant organizations is a valuable standard of how cities are confronting the rising politicization of immigration and how immigrants, as a collective actor, are included in the political decisions that affect their lives. The fact that politicians representing political parties and leaders from immigrant organizations live in the same territorial space facilitate the daily interaction that forges alliances. Moreover, this study shows that independently of national structures, local resources can become essential in the formation of alliances. The study of alliances locally opens the scope for further research regarding specific relationships and their effects on the policy-making of immigration as well as the way political parties can shape the mobilization and organization of immigrants from a multi-level approach. 


\section{References}

Alba, R., and N. Foner. 2015. Strangers no more: Immigration and the challenges of integration in North America and Western Europe. Princeton University Press.

Allern, E., and T. Bale. 2012. "Political parties and interest groups. Disentangling complex relationships." Party Politics, 18(1), 7-25.

Arango, J., E. Brey, Y. Maldonado, and D. Moualhi. 2011. "Country context paper”. Research reports, Universidad Complutense de Madrid, October.

Axelrod, R. 1970. Conflict of Interest. A theory of Divergent Goals with applications to Politics. Chicago: Markham.

Borkert, M., and T. Caponio. 2010. The Local Dimension of Migration Policymaking. Amsterdam: IMISCOE-AUP.

Bousetta, H. 2000. "Institutional Theories of immigrant ethnic mobilization: Relevance and limitations." Ethnic and Migration Studies, 26 (2): 229-245. doi: 10.1080/13691830050022785.

Boyatzis, R. 1998. Transforming qualitative information: Thematic analysis and code development. Thousand Oaks, CA: Sage.

Braun, V., and V. Clarke. 2006. "Using thematic analysis in psychology." Qualitative Research in Psychology, 3 (2): 77-101. URL: http://dx.doi.org/10.1191/1478088706qp063oa.

Breton, R. 1964. "Institutional completeness of ethnic communities and the personal relations of immigrants." American Journal of Sociology, 70 (2): 193-205. URL: http://www.jstor.org/stable/2775209.

Burchianti, F. and R. Zapata-Barrero. 2014. "Is Catalonia immune to racism? An analysis of intolerant political discourses of mainstream party representatives." Journal of Immigrant \& Refugee Studies, 12(4): 401-417.

Caponio , T. 2005. "Policy Networks and Immigrants' Associations in Italy: The Cases of Milan, Bologna and Naples." Journal of Ethnic and Migration Studies. 31 (5). doi: $10.1080 / 13691830500177891$

Cappiali, T. 2016. "Activism of immigrants in vulnerable conditions and radical-left allies: a case study of Italy's Struggle of the Crane." Journal of Ethnic and Migration Studies, 1-20. doi: http://dx.doi.org/10.1080/1369183X.2016.1169917.

Clark, P. and J. Wilson. 1961. "Incentive systems: A theory of organizations."Administrative Science Quarterly, 6 (2): 129-166. doi: 10.2307/2390752.

Cox, G. 1997. Making votes count: strategic coordination in the world's electoral systems. Cambridge University Press.

de Graauw, E. and F, Vermeulen. 2016. "Cities and the Politics of Immigrant Integration: A Comparison of Berlin, Amsterdam, New York City, and San Francisco." Journal of Ethnic and Migration Studies. doi: 10.1080/1369183X.2015.1126089.

Diani, M. 2015."Building civic networks: Logics of tie formation." In: M. Diani (ed.). The cement of civil society. Cambridge: Cambridge.

Diani, M., and I. Bison. 2004. "Organizations, coalitions and movements." Theory and Society, 33: 281-309. URL: http://www.jstor.org/stable/pdf/4144874.pdf?acceptTC=true.

Dowding, K. 1991. Rational choice and political power. Aldershot: Edward Elgar. 
Edwards, B., and J. McCarthy. 2004. "Resources and social movement mobilization." In: The Blackwell Companion to Social Movements. Edited by: D. Snow; A. Sarah \& H. Kriesi. Oxford: Blackwell.

Fennema, M. and J. Tillie. 2001. "Political Participation and Political Trust in a Multicultural Democracy, Civic Communities and Ethnic Networks in Amsterdam." Journal of Ethnic and Migration Studies, 25(4), 703-726. doi: 10.1080/1369183X.1999.9976711.

Galaskiewicz, J. 1985. "Interorganizational relations." Annual review of sociology, 11: 281-304. doi: 10.1146/annurev.so.11.080185.001433.

Garbaye, R. 2005. Getting into the local power. The politics of ethnic minorities in British and French cities. Oxford: Blackwell.

Giugni M. and F. Passy. 1998. "Social Movements and Policy Change: Direct, Mediated, or Joint Effect?" American Sociological Association Section on Collective Behaviour. Working Paper Series, 1 (4).

Giugni, M. and Morales, L. 2011. Social Capital, Political Participation and Migration in Europe. Migration, Minorities and Citizenship. Basingstoke: Palgrave.

Hochshild, J. and J. Mollenkopf. 2009. Bringing outsiders in: Trans-Atlantic perspectives in immigrant incorporation. Ithaca: Cornell University Press.

Ireland, P. 2004. Becoming Europe: Immigration, Integration, and the Welfare State. Pittsburh: Pittsburgh.

Iskander, N. 2007. "Informal work and protest: undocumented immigrant activism in France, 1996-2000." British Journal of Industrial Relations, 45(2): 309-334.

Jones-Correa, M. 2005. "Bringing Outsiders In: Questions of Immigrant Incorporation.” In: The Politics of Democratic Inclusion. Edited by C. Wolbrecht and R. E. Hero. Philadelphia: Temple University.

Knoke, D. 1988. "Incentives in Collective Action Organizations." American Sociological Review, 53 (3): 311-329. URL: http://www.jstor.org/stable/2095641.

Knoke, D., and C. Wright-Isak. 1982. "Individual motives and organizational incentive systems." Research in the Sociology of Organizations, 1(2): 209-254.

Koopmans, R., and P. Statham. 2000. "Migration and ethnic relations as a field of political contention: An opportunity structure approach." In: Challenging immigration and ethnic relations politics. Comparative European perspectives. Edited by R. Koopmans and P. Statham. Oxford: Oxford, 13- 56.

Koopmans, R., P. Statham, M. Giugni, and F. Pessy. 2005. Contested citizenship: Immigration and cultural diversity in Europe. Minneapolis: University of Minnesota.

Kriesi, H. 2004. "Political Context and Opportunity." In: The Blackwell Companion to Social Movements. Edited by: D. Snow; A. Sarah and H. Kriesi. Oxford: Blackwell.

Kriesi, H. 2015. "Party Systems, Electoral Systems, and Social Movements." In: The Oxford Handbook of Social Movements. Edited by D. Della Porta and M. Diani. Oxford: Oxford.

Kriesi, H., R. Koopmans, J. Duyvendak, and M. Giugni. 1995. New Social movements in Western Europe. A comparative analysis. London: UCL Press Limited.

Martiniello, M. 1993. "Ethnic leadership, ethnic communities' political powerlessness and the state in Belgium." Ethnic and racial studies, 16 (2): 236-255. doi: 10.1080/01419870.1993.9993781.

McCarthy, J., and M. Zald. 1973. The Trend of Social Movements in America: Resource Mobilization and Professionalization. Morristown: General Learning. 
Meyer, D., and S. Staggenborg. 1996. "Movements, countermovements, and the structure of political opportunity." American Journal of Sociology, 101 (6): 1628-1660. URL: http://www.jstor.org/stable/2782114?seq=1\#page_scan_tab_contents.

Morris, A., and S. Staggenborg. 2004. "Leadership in social movements." The Blackwell companion to social movements. Oxford: Blackwell.

Però, D. 2007. "Migrants and the politics of governance. The case of Barcelona." Social Anthropology, 15(3), 271-286.

Però, D., and Solomos, J. 2010. "Introduction: migrant politics and mobilization: exclusion, engagements, incorporation." Ethnic and Racial Studies, 33(1): 1-18.

Ramakrishnan, S. and I. Bloemraad (eds). 2008. Civic Hopes and Political Realities. Immigrants, Community Organizations, and Political Engagement. New York: Russell Sage Foundation.

Rucht, D. 2004. "Movements, Allies and Adversaries." In: The Blackwell Companion to Social Movements. Edited by D. Snow; A. Sarah \& H. Kriesi. Oxford: Blackwell.

Ruedin, D., and S. Meyer. 2014. "Politicization from below? The deportation issue in public discourse in Austria, Switzerland, and Germany." URL: http://ssrn.com/abstract=2480614.

Seawright, J., and J. Gerring. 2008. "Case Selection Techniques in Case Study Research: A Menu of Qualitative and Quantitative Options.” Political Research Quarterly, 61: 294-308. doi: 10.1177/1065912907313077.

Smith, J. and T. Fetner. 2010 "Structural Approaches in the Sociology of Social Movements". In: Handbook of Social Movements Across Disciplines. Edited by B. Klandermans and C. Roggeband, 13-57. New York: Springer.

Strom, K. 1990. "A behavioral theory of competitive political parties." American Journal of Political Science, 34 (2): 565-598.

Suchman, M. 1995. "Managing legitimacy: Strategic and institutional approaches." Academy of Management Review, 20 (3): 571-610. URL: http://www.jstor.org/stable/258788

Tarrow, S. 1994. Power in Movement: Social Movements, Collective Action and Politics. Cambridge: Cambridge.

Triviño-Salazar, J.C. 2014. "Immigrant organizations and the politicization of cultural diversity in the city." Analytical Note, 2014/03. Robert Schuman Centre. European University Institute.

van der Brug, W., G. D'Amato, D. Ruedin, and J. Berkhout. 2015. The politicization of immigration. New York: Routledge.

Vermeulen, F. 2006. The Immigrant Organising Process, Turkish Organisations in Amsterdam and Berlin and Surinamese Organisations in Amsterdam 1960-2000. Amsterdam:

Amsterdam University Press. 